\title{
НАУКОВИЙ ГЕНЕЗИС ПРОБЛЕМАТИКИ ПРОВЕДЕННЯ ОПЕРАТИВНО-РОЗШУКОВИХ ЗАХОДІВ ПІДРОЗДІЛАМИ КРИМІНАЛЬНОї ПОЛІЦІї
}

Капустник В. В.

у статmі проводиться дослідження становлення та розвитку в наукових працях питань проведення оперативно-розшукових заходів підрозділами кримінальної поліції, еволюції розвитку цієї невід'ємної частини оперативно-розшукової діяльності. Наголошується, що постановка проблем наукового генезису має розглядатися як актуальна і така, що має науково-практичне значення, задача, вирішення якої спрямовано на вдосконалення практики протидіі злочинності.

3'ясовано, що в радянський період оперативно-розшукова діяльність розглядалася як складник криміналістики. Крім того, специфічний, переважно негласний характер оперативно-розшукової діяльності визначив досить насторожене ставлення до ії теоретичних проблем із боку окремих вчених, які вважали, що курс оперативно-розшукової діяльності - це суто практична дисципліна, а методи, прийоми, заходи, які застосовуються при цьому, настільки різноманітні, наскільки різноманітні злочинні прояви.

Зроблено висновок, що на сучасному етаni розвитку юридичної науки теорія проведення оперативно-розшукових заходів накопичила величезний емпіричний матеріал і на його основі визначила систему окремих понять, категорій, сформулювала низку практичних рекомендацій. Наголошено, що набуття Україною незалежності і прийняття закону про оперативно-розшукову діяльність стало поштовхом для наукового осмислення вченими підстав та умов проведення оперативно-розшукових заходів, порядку їх проведення й використання отриманих результатів у кримінальному судочинстві.

Hamenep теорія дослідження проведення оперативно-розшукових заходів підрозділами кримінальної поліціі увійшла в найважчий етап свого становлення, який характеризується конкретизацією їі предмета, методів і систем проведення, формулюванням світоглядних принципів i теоретичних концепцій. Успішна розробка та завершення комплексних досліджень, які стосуються проведення оперативно-розшукових заходів підрозділами кримінальноі поліції, зробить вагомий внесок у розвиток теорії оперативно-розшукової діяльності, надасть допомогу практиці, дозволить покращити якість навчального процесу, підвищить наукову кваліфікацію викладачів.

Ключові слова: аналіз, науковий генезис, оперативно-розшукові заходи, оперативно-розшукова діяльність, оперативні підрозділи.

В статье проводится исследование становления и развития в научных трудах вопросов проведения оперативно-розыскных мероприятий подразделениями криминальной полиции, эволюция развития этой неотъемлемой части оперативно-розыскной деятельности. Отмечается, что постановка проблем научного генезиса должна рассматриваться как актуальная и имеющая научно-практическое значение, задача, решение которой направлено на совершенствование практики противодействия преступности.

Капустник В. В., 2019
Установлено, что в советский период оперативно-розыскная деятельность рассматривалась как составная часть криминалистики. Кроме того, специфический, преимущественно негласный характер оперативно-розыскной деятельности определил достаточно настороженное отношение к ее теоретических проблемам со стороны отдельных ученых, которые считали, что курс оперативно-розыскной деятельности - это сугубо практическая дисциплина, а методы, приемы и меры, применяемые при этом, настолько разнообразны, насколько разнообразны преступные проявления.

Сделан вывод, что на современном этапе развития юридической науки теория проведения оперативно-розыскных мероприятий накопила огромный эмпирический материал и на его основе определила систему отдельных понятий, категорий, сформулировала ряд практических рекомендаций. Отмечено, что предоставление Украины независимости и принятие закона об оперативно-розыскной деятельности стало толчком для научного осмысления учеными оснований и условий проведения оперативно-розыскных мероприятий, порядка их проведения и использования полученных результатов в уголовном судопроизводстве.

На сегодняшний день теория исследования проведения оперативно-розыскных мероприятий подразделениями криминальной полиции вошла в тяжелый и сложный этап своего становления, который характеризуется конкретизацией ее предмета, методов и системы проведения, формулировкой мировоззренческих принципов и теоретических концепций. Успешная разработка и завершения комплексных исследований, касающихся проведения оперативно-розыскных мероприятий подразделениями криминальной полиции, внесет весомый вклад в развитие теории оперативно-розыскной деятельности, окажет помощь практике, позволит улучшить качество учебного процесса, повысит научную квалификацию преподавателей.

Ключевые слова: анализ, научный генезис, оперативно-розыскные мероприятия, оперативно-розыскная деятельность, оперативные подразделения.

The article studies the formation and development in scientific works of the issues of conducting operational-search activities by criminal police units, the evolution of the development of this integral part of operational-search activities. It is noted that the formulation of the problems of scientific genesis should be regarded as relevant and of scientific and practical importance, a task whose solution is aimed at improving the practice of combating crime. It has been found that in the soviet period science and search activities were generally regarded as an integral part of forensic science.

In addition, the specific, largely unspoken, nature of the investigative activity identified a rather cautious attitude toward its theoretical problems by some scientists, who believed that the course of investigative activity was a purely practical discipline, and the methods, techniques and measures used at the same time, they are as diverse as the various criminal acts. 
It is concluded that at the current stage of the development of legal science, the theory of operational investigative measures has accumulated enormous empirical material and on its basis has determined a system of individual concepts, categories, formulated a number of practical recommendations. It is noted that the acquisition of independence by Ukraine and the adoption of the law on operative-search activities became the impetus for the scientific understanding of the grounds and conditions for conducting operational-search measures by scientists, the procedure for their conduct and the use of the results in criminal proceedings.

To date, the theory of research on the conduct of operational-search measures by criminal police units has entered a difficult stage in its formation, characterized by the concretization of its subject, methods and system of conduct, the formulation of philosophical principles and theoretical concepts. The successful development and completion of comprehensive research related to the conduct of operational-search activities by criminal police units will make a significant contribution to the development of the theory of operational-search activities, will help practice, will improve the quality of the educational process, and undoubtedly increase the scientific qualifications of teachers.

Key words: analysis, scientific genesis, operational-search measures, operational-search activities, operational units.

Постановка проблеми та їі актуальність. Своєчасне виявлення й нейтралізація загроз правопорядку в державі, забезпечення безпеки громадян країни $\epsilon$ одним із завдань правоохоронних органів і підрозділів кримінальної поліції (далі - ПКП). Логічно, що наявність певних державних структур, які забезпечуватимуть виконання вказаних вище завдань, визначає необхідність інструментарію та відповідної методики до його використання. Зважаючи на те, що чимала частина злочинів готується та вчиняється в умовах неочевидності, з елементами несподіваності й високого професіоналізму тільки адекватна відповідь уповноважених суб'єктів стане тією ефективною силою, спроможною діяти проти злочинців системно, на випередження, використовуючи весь арсенал сил, засобів та оперативно-розшукових заходів (далі - ОРЗ).

Протягом тривалого часу така діяльність становила прообраз оперативно-розшукової діяльності (далі ОРД) і проводилася таємно, конспіративно, зашифровано без будь-якої гласної чи негласної наукової бази та законодавчої регламентації. 3 переростанням державних утворень у повноцінні держави, з розвитком у них суспільних відносин та їх ускладненням, зміцненням централізованої влади відбувалося посилення ролі державних органів у боротьбі зі злочинністю.

Правовий, соціально-економічний і політичний розвиток держав, боротьба за владу примусили можновладців звернути особливу увагу на органи правопорядку та потребу їх розвитку у частині упорядкування, систематизації та розвитку спеціальної діяльності та навичок здобуття інформації, спроможної забезпечити безпеку як держави, так і провладних інтересів.

Зважаючи на вказані обставини, постановка проблем наукового генезису питань проведення ОРЗ підрозділами кримінальної поліції, еволюції розвитку ОРЗ та історичного досвіду їх організації має підставу розглядатися як актуальна, велика і така, що становить важливе теоретичне та науково-практичне значення, задача, вирішення якої спрямовано на вдосконалення практики протидії злочинності, розробку стратегії державної політики у сфері зміцнення підвалин правової держави.
Враховуючи зазначене, автор вважає важливим для визначення концептуальних засад проведення ОРЗ ПКП дослідження наукового генезису проблематики проведення цих заходів, що й окреслює мету статті.

Виклад основного матеріалу. Спираючись на доступні для аналізу літературні джерела, сьогодні можна зробити висновок, що перше документальне згадування питання наукового підходу застосування прототипу ОР3 у протидії злочинам на державному рівні було реалізовано у 1467 році під час дії Псковської судної грамоти, в якій була встановлена обов'язкова участь представника держави в розслідування крадіжок. Ці положення у подальшому були закріплені у Судебниках 1497 та 1550 років, а також у Соборному Укладенні 1649 року. О.І. Александров у своїй монографії зазначав, що у той час широкого розповсюдження набули такі заходи як стеження та виказування. Автором зазначив, що вже в той період особи, які сприяли на негласній основі правоохоронній системі держави, мали присягати на вірність государю [1].

Характеризуючи радянський період до середини 50-х років, можна сказати, що недоліки узагальнення оперативно-розшукової практики, упущення в іï теоретичному осмисленні стало результатом недостатнього розвитку наукових досліджень відповідних теоретичних проблем, у тому числі наукових підходів до організації і проведення ОРЗ.

У радянський період наука ОРД загалом розглядалася як складник криміналістики. Крім того, специфічний, переважно негласний характер ОРД визначив насторожене ставлення до її теоретичних проблем із боку окремих вчених, які вважали, що курс ОРД - це суто практична дисципліна, а методи, прийоми і заходи, які застосовуються при цьому, настільки різноманітні, наскільки різноманітні злочинні прояви. Ця обставина і змушує практичних працівників діяти в основному по обстановці, а не по науці.

Відсутність планомірної наукової розробки актуальних проблем теорії ОРД, недооцінка результатів проведених досліджень часто породжували на практиці суто емпіричний підхід до організації і тактики проведення ОРЗ з метою боротьби зі злочинністю [2, с. 5]. Лише в 1971-1973 роках у спеціальній літературі на основі проведених досліджень було подано переконливо обґрунтований висновок про необхідність і реальну можливість визнання теорії ОРД самостійною галуззю наукового знання (наприклад, статті Д.В. Гребельського «О некоторых проблемах профессиональной подготовки кадров и развития теории оперативно-розыскной деятельности органов внутренних дел», 1972 год; Д.В. Гребельського, Г.К. Синилова «О развитии теории оперативно-розыскной деятельности", 1972 год; А.І. Алексєєва, Г.К. Синилова «Некоторые теоретические проблемы оперативно-розыскной деятельности», 1972 год). У цій статті з погляду на їі мету автор не збирається оскаржувати результати, наведені у вивчених працях фахівців. Він намагається хронологічно прослідкувати генезу розвитку напрямів теорії проведення ОРЗ оперативними підрозділами (підрозділами кримінальної поліції зокрема).

Після першої спроби дати загальну оцінку проаналізованим працям можна констатувати, що наукові інтереси, які стосуються питань ОРЗ, достатньо різнобічні. Проте в цій різнобічності помітно простежується зако- 
номірність: більшість досліджуваних питань присвячено особливостям проведення ОРЗ на тому чи іншому конкретному напрямі протидії злочинності.

Перед розкриттям питання статті насамперед необхідно визначитися 3 об'єктом дослідження. Автор зазначає, що з точки зору філософської теорії пізнання об'єкт - це те, на що спрямоване пізнання. Тобто, це та частина реальності, на розуміння якої спрямовані зусилля дослідників. Цією реальністює об'єктивно існуючі суспільні відносини, які виникають під час здійснення ОРД. Саме такі суспільні відносини і є об'єктом теорії ОРД. Логічним буде стверджувати, що об'єктом теорії ОРЗ $є$ саме такі суспільні відносини, які виникають при здійсненні ОРЗ і використанні їх результатів.

Ґрунтуючись на філософській теорії пізнання, предметом ОРД у широкому сенсі (об'єктивним змістом, яке вона вивчає) $\epsilon$ реально існуючий (незалежно від ступеня його усвідомлення) процес діалектичних відносин (протидіï) держави (в особі ПКП) і злочинності, найважливішою стороною якого $\epsilon$ становлення оперативно-розшукової практики і кримінальної активності [3, с. 103]. Стосовно ОРД виділяють такі закономірності, які визначають:

- потребу у здійсненні ОРД і перспективи ії розвитку на певний період часу;

- функціонування системи управління у сфері ОРД;

- зміст організаційно-тактичних форм, методів і тактичних прийомів оперативно-розшукової протидії злочинності [4, с. 98-99].

Предмет теорії ОРЗ вужчий за предмет ОРД. До нього належать такі закономірності: про ОР3;

систематизації теоретико-методологічних робіт

практики проведення ОРЗ за окремими видами злочинів;

розвиток законодавства, що регламентує порядок проведення ОР3;

- виникнення ОРЗ і потреби їх проведення;

- використання результатів ОРЗ в ОРД, досудовому

розслідуванні та судовому розгляді кримінальних проваджень;

подальший розвиток теорії оперативно-розшукових заходів.

Не заперечуючи нагальної важливості та практичної цінності цих закономірностей, слід зазначити, що фундаментальні питання теорії проведення ОР3 підрозділами кримінальної поліції ще не стали предметом прискіпливої уваги та інтересу з боку вчених. Ними займаються тільки окремі дослідники.

До праць, присвячених вивченню питання теорії OP3, можна віднести наукові розробки багатьох фахівців у різні роки, але систематичним вивченням питання займалося не так багато вчених. До найбільш відомих теоретико-методологічних робіт про ОРЗ належать праці Є.А. Мітрофанова «Оперативно-розшукові дії: поняття, типологія, тактика» (1987 рік, навчальний посібник); О.Ф. Долженкова, В.П. Євтушка, В.Л. Ортинського, М.Б. Саакяна «Оперативно-тактичні операції» (2004 рік, монографія); І.В. Сервецького, Г.О. Якименка «Теорія оперативно-розшукових заходів» (2006 рік, монографія); Ю.Ю. Орлова «Застосування оперативної техніки в оперативно-розшуковій діяльності міліції (теорія і практика)» (2007 рік, монографія); М.М. Перепелиці, О.В. Манжая, В.В. Шендрика «Здійснення опе- ративно-розшукових заходів шляхом використання кіберпростору» (2009 рік, монографія); О.М. Бандурки, М.М. Перепелиці, О.В. Манжая, В.В. Шендрика «Оперативно-розшукова компаративістика» (2013 рік, монографія); І.Р. Шинкаренка, О.В. Кириченка, А.М. Ханькевича «Система оперативно-розшукових заходів» (2015 рік, навчальний посібник). У наведених працях автори намагалися висвітлити більшість закономірностей предмету теорії і практики ОР3, побудувати чітку систему нових знань, які розкривають поняття і зміст ОР3, iї правову й функціональну сутність як об'єкта наукового вивчення, а також методологічні основи пізнання із проведення ОРЗ як практичної категорії.

Удосконаленню нормативно-правового регулювання OР3 присвячено чимало уваги фахівців. Вивчення оперативно-розшукової, слідчої, прокурорської та судової практики свідчить про те, що наявність у законодавстві пробілів і неузгодженостей, які стосуються питань проведення ОРЗ оперативними підрозділами (ПКП), призводить до вкрай неефективного правозастосовчого процесу, зайвої витрати сил, засобів, коштів і часу правоохоронців. Разом із тим, не можна стверджувати, що питанням нормативно-правового забезпечення приділено за роки незалежності України достатньо уваги. Серед робіт, присвячених саме цьому питанню, можна виокремити роботи: монографія О.А. Гапона та І.Р. Шинкаренка «Оперативно-розшукові і розвідувально-пошукові заходи: нормативне регулювання» (2002 рік); статті Д.Є. Завідонова «Нормативне регулювання оперативно-розшукових заходів в організованих злочинних наркоугрупуваннях, сформованих за етнічною ознакою» (2002 рік); В.Ю. Журавльова «Нормативне регламентування оперативно-розшукових заходів - вимога часу» (2003 рік); М.Г. Жуковської «Вдосконалення відомчого правового регулювання оперативно-розшукових заходів» (2003 рік); С.В. Сапегіна «Визначення заходів ОРД як правових норм цієї діяльності та підстав щодо їх застосування» (2004 рік); М.А. Погорецького «Проблеми правового регулювання превентивних заходів в ОРД» (2004 рік); Б.І. Бараненка, Е.О. Дідоренка «Комплексно-системне застосування ОРЗ і засобів в ОРД: правові, теоретичні, методологічні і прикладні аспекти» (2004 рік); О.П. Снегірьова «Підстави для проведення оперативно-розшукових заходів» (2004 рік); С.М. Кряковцева «Правове регулювання застосування оперативно-технічних засобів при проведенні оперативно-розшукових заходів» (2005 рік); В.Я. Горбачевського «Правові підстави застосування оперативно-розшукових заходів для розкриття умисних вбивств із кваліфікуючими ознаками» (2009 рік); О.В. Бочкового «Сучасний стан дотримання законності при отриманні дозволу на проведення оперативно-розшукових заходів, що тимчасово обмежують конституційні права громадян» (2009 рік); О.Л. Христова «Правова регламентація оперативного впізнання» (2013 рік); Р.М. Римарчука «Правові підстави проведення негласних слідчих (розшукових) дій і здійснення оперативно-розшукових заходів» (2013 рік); Т.М. Карпинця «Оперативно-розшукові заходи: вдосконалення правового регулювання (2013 рік); А.В. Федотенка «Напрями вдосконалення відомчого нормативного регулювання провадження технічної розвідки у злочинному середовищі» (2014 рік); О.В. Кондратюка «Проблеми правового регулювання застосування оперативно-розшукових заходів для розшуку осіб, 
які переховуються від органів досудового розслідування, слідчого судді, суду» (2016 рік) та «Законність застосування оперативно-розшукових заходів у кримінальному провадженні» (2017 рік); М.С. Одарченко «Дотримання законності під час здійснення оперативно-розшукових заходів» (2017 рік); 0.О. Шаповалова «Правові основи проведення оперативно-розшукових заходів при виявленні ознак злочинів» (2017 рік); Р.М. Мрочка «Правова регламентація оперативного впізнання» (2018 рік); В.В. Мацака «Відомче правове регулювання дотримання гарантій законності під час здійснення аудіо- та відео контролю особи» (2018 рік); О.С. Пономаренко «Співвідношення прав оперативних підрозділів Державної прикордонної служби України і оперативно-розшукових заходів» (2018 рік). Крім системного монографічного дослідження О.А. Гапона та І.Р. Шинкаренка (2002 рік), інші роботи охоплювали значно вужче коло питань, які стосуються нормативно-правової проблематики проведення ОРЗ.

Поняттю ОРЗ як предмету наукового дослідження присвячено чимало праць вітчизняних і зарубіжних вчених, в яких виявлено понад 30 його формулювань. Різне розуміння вказаного терміну призводить до того, що в законодавстві, відомчих нормативно-правових актах і на практиці нерідко до ОРЗ зараховують заходи, що не відповідають їх змісту (організаційні, які здійснюються в межах ОРД, оперативно-розшукові операції, що за своєю гносеологічною і правовою природою мають інше змістове значення) [5, с. 85-86].

Наукова і правова невстановленість поняття ОРЗ та їх переліку і класифікації актуалізує теоретичну й законодавчу розробку окресленої проблеми, що має практичне значення [5, с. 86]. В Україні зазначені проблеми досліджувалися і були відображені у працях С.О. Юдіна «До поняття «оперативно-розшукові заходи» (2005 рік); Б.К. Слободянюка «Проблеми визначення поняття оперативно-розшукових заходів» (2005 рік); І.В. Сервецький, Г.О. Якименко «Теоретичні засади оперативно-розшукових заходів» (2006 рік); Р.Ф. Черниша «Оперативно-розшукові заходи: поняття, види та сутність (2009 рік); В.В. Матвійчука «Методи і заходи як категорії оперативно-розшукової діяльності» (2009 рік); О.В. Темнікова «Щодо визначення сутнісних ознак оперативно-розшукових заходів» (2011 рік); А.В. Мовчана «Співвідношення термінів «оперативно-розшукові заходи», «оперативно-розшукові засоби», «оперативно-розшукові методи» й «негласні слідчі (розшукові) дії» (2013 рік); І.В. Сервецького, А.Ю. Неманова «Щодо класифікації оперативно-розшукових заходів» (2012 рік); М.Г. Рижова «Система оперативно-розшукових заходів і негласних слідчих дій» (2012 рік); М.А. Погорецького, Д.Б. Сергєєвої «Негласні слідчі (розшукові) дії та оперативно-розшукові заходи: поняття, сутність і співвідношення» (2014 рік); М.Г. Рижова «Структура оперативно-розшукових заходів» (2013 рік); Є.Л. Малишенка «Систематизація оперативно-розшукових заходів органів внутрішніх справ України за правовим режимом їх проведення підрозділами Державної служби боротьби з економічною злочинністю» (2014 рік); М.Л. Грібова «Класифікація оперативно-розшукових заходів: традиційні підходи та сучасні реалії» (2016 рік).

Вчені та практичні працівники ПКП знають, яке велике значення мають дослідження особливостей проведення ОРЗ за окремими видами злочинів. Такі роботи повинні підняти завісу над досі маловивченими питаннями теорії і практики проведення ОРЗ. Саме цим питанням здебільшого приділяють увагу дослідники у своїх працях. Шляхом аналізу спеціальної літератури визначені напрями досліджень різних років, які $\epsilon$ актуальними і натепер:

особливості проведення ОРЗ для встановлення осіб крадіїв на транспорті (В.С. Назаров, 1976 рік; П.Я. Мінка, 2004 рік; К.В. Шахова, 2015 рік);

- особливості проведення ОРЗ для встановлення осіб крадіїв транспортних засобів (С.А. Шкода, 2011 рік);

особливості проведення першочергових ОРЗ у процесі встановлення осіб ґвалтівників (М.С. Бєкмурзін, 1986 рік); особливості проведення невідкладних ОРЗ для протидії викраденню людей (Т. Утмєлідзе, 1988 рік; А.В. Криворучко);

проведення ОРЗ під час протидії заворушенням і масовим безладдям на націоналістичному підґрунті (П.Н. Кінаш, В.В. Марцинкевич, 1989 рік; М.М. Єфімов, 2012 рік);

особливості проведення ОРЗ у протидії ПКП злочинності неповнолітніх (О.П. Снігерьов, І.М. Колошко, 1993 рік; А.І. Гайдар, 2005 рік);

особливості проведення ОРЗ у протидії ПКП навмисним вбивствам і тяжким тілесним ушкодженням (І.М. Колошко, 1997 рік; О.В. Киричко, 2008 рік; В.Я. Горбачевський, 2008 рік; О.І. Савка, А.М. Ханькевич, 2018 рік);

особливості проведення ОРЗ у протидії ПКП серійним вбивствам (Ю.Е. Черкасов, В.Я. Горбачевський, 2003 рік; О.В. Александренко, 2016 рік);

особливості проведення ОРЗ щодо виявлення осіб, які вчиняють розбійні напади на квартири громадян (В.Г. Телічук, 2004 рік);

- застосування ОРЗ для протидії злочинам корисливої спрямованості (О.Ф. Кобзар, 2006 рік; О.М. Асадчих, 2012 рік);

особливості проведення ОРЗ у протидії наркозлочинності (М.О. Сергатий, Є.Л. Солдатова, 2006 рік; Л.Г. Шарай, 2009 рік; І.М. Копотун, 2013 рік);

- особливості проведення ОРЗ для протидії злочинам терористичного спрямування (В.В. Літвін, 2006 рік); особливості проведення ОРЗ щодо виявлення ознак злочинів в економічній сфері (В.В. Матвійчук, І.М. Пустовіт, 2006 рік; Д.М. Середа, 2007 рік; В.О. ЄлісєєВ, 2008 рік; С.Г. Бевзенко, 2011 рік; І.Г. Проскурняк, 2016 рік);

- особливості проведення першочергових ОРЗ у протидії корисливо-насильницьким злочинам (O.І. Козаченко, 2007 рік);

особливості проведення ОРЗ для викриття злочинів, пов'язаних з отриманням неправомірної вигоди (Г.О. Пушкарьов, 2008 рік; Л.С. Бєлік, 2009 рік);

- особливості проведення ОРЗ у протидії комп'ютерній злочинності (В.М. Бутузов, 2010 рік);

особливості проведення ОРЗ у протидії вимаганням (О.М. Горбань, 2012 рік);

особливості використання ОРЗ з метою фіксації фактів порушення авторського права і суміжних прав (Н.В. Гангур, 2018 рік);

особливості проведення ОРЗ з метою протидії шахрайству через мережу Інтернет (О.І. Кривенко, 2018 рік). 
До робіт, в яких розкриваються загальні проблеми проведення ОРЗ та які характеризують подальший розвиток теорії ОР3, можна віднести роботи за такими напрямами:

внутрішня та зовнішня взаємодія під час проведення ОР3: М.А. Погорецький «Взаємодія оперативно-розшукових підрозділів i органів досудового слідства: проблеми використання протоколів оперативно-розшукових заходів як доказів у кримінальному процесі (2002 рік); Є.В. Курінний «Організація взаємодії УОС УМВС із гласними оперативними підрозділами під час підготування та проведення негласних оперативно-розшукових заходів (2004 рік); О.В. Коваленко «Організація взаємодії спеціальних підрозділів БОЗ 3 іншими правоохоронними органами при здійсненні оперативно-розшукових заходів із використанням ОТЗ» (2004 рік); В.Є. Тарасенко «Взаємозв’язок агентурного методу із заходами оперативно-розшукової діяльності» (2010 рік); О.М. Махлай «Особливості взаємодії Державної прикордонної служби України з іншими правоохоронними органами у процесі підготовки та проведення спільних оперативно-розшукових заходів» (2017 рік);

планування ОР3: Д.М. Середа «Організаційні основи планування оперативно-розшукових заходів OPC», «Захист» документування злочинів, вчинених злочинними групами» (2011 рік); В.В. Топчій «Спільне планування слідчих дій і оперативно-розшукових заходів під час розслідування злочинів» (2011 рік);

- використання оперативної техніки під час проведення ОРЗ: Я.Ю. Кондратьєв «Застосування оперативної техніки під час проведення оперативно-розшукових заходів (2006 рік); Д.К. Гарматін, Л.Є. Болясов, Ф.М. Нагорський, І.О. Плешкановський «Системи технічних засобів із забезпечення оперативно-розшукових заходів: міжнародний досвід» (2006 рік); Ю.В. Степанов «Використання комп'ютерних засобів під час оперативно-розшукових заходів із викриття злочинної діяльності осіб, що розроблюються» (2010 рік) та «Використання комп'ютерних засобів під час проведення оперативно-розшукових заходів» (2010 рік); А.В. Федотенко «Теоретичні, правові, організаційні та тактичні засади діяльності оперативно-технічних підрозділів Національної поліції щодо протидії злочинності» (2017 рік);

- тактика проведення ОРЗ: В.І. Лазутко «Організація і тактика оперативно-технічного документування» (2000 рік); Я.Ю. КондратьєВ, Д.Й. Никифорчук, О.М. Сніцар «Тактика проведення оперативно-розшукових заходів та особливості легалізації оперативно-розшукової інформації» (2004 рік); С.І. Кобзар «Організаційно-тактичні особливості виявлення, фіксації та вилучення слідів рук при здійсненні оперативно-розшукових заходів» (2004 рік); А.Ю. Журавльов «Тактика здійснення окремих першочергових оперативно-розшукових заходів» (2006 рік) і «Тактичні особливості здійснення деяких наступних оперативно-розшукових заходів» (2007 рік); М.О. Кисельов «Оперативно-розшукові заходи органів внутрішніх справ щодо запобігання вчиненню злочинів у великому місті» (2008 рік); Л.Є. Паланичко «Проведення оперативно-розшукових заходів щодо запобігання злочинам в умовах великого міста» (2012 рік); В.В. Мишко «Організація і тактика першочергових оперативно-розшукових заходів протидії злочинам» (2013 рік); А.О. Шапарь «Тактика проведення оперативно-розшукових заходів по перевірці джерел і змісту оперативної інформації» (2013 рік); В.О. Біляєв «Сучасні тактичні основи використання оперативно-розшукових заходів підрозділами карного розшуку» (2013 рік); Я.О. Морозова «Організаційно-тактичні особливості проведення оперативно-розшукових заходів у процесі протидії організованій злочинності загальнокримінальної спрямованості» (2018 рік);

- відомчий і судовий контроль та прокурорський нагляд за дотриманням законності під час проведення ОРЗ: В.Л. Ортинський «Відомчий контроль при проведенні оперативно-розшукових заходів - необхідний складник дотримання конституційних прав і свобод людини (2009 рік); В.В. Віхров «Деякі аспекти процедури організації та здійснення судового контролю за застосуванням оперативно-розшукових заходів» (2008 рік) і «Судовий контроль за застосуванням оперативними підрозділами органів внутрішніх справ оперативно-розшукових заходів» (2010 рік); О.Г. Рибак «Контрольна функція суду за дотриманням конституційних прав і свобод людини при проведенні оперативно-розшукових заходів» (2009 рік) i «Прокурорський нагляд за дотриманням законності при проведенні оперативно-розшукових заходів» (2009 рік); О.О. Байов «Процедура надання судового дозволу на проведення оперативно-розшукових заходів, пов'язаних із тимчасовим обмеженням прав громадян» (2009 рік); В.О. Глушков «Судовий контроль за дотриманням прав людини при наданні дозволу на проведення окремих оперативно-розшукових заходів» (2010 рік); Д.В. Чижиченко «Принципи судового контролю за використанням інституту обмеження прав і свобод людини під час провадження оперативно-розшукових заходів» (2014 рік); А.В. Вінаков «Прокурорський нагляд за оперативно-розшуковою діяльністю органів внутрішніх справ, яка здійснюється 3 використанням інформаційно-телекомунікаційних систем» (2014 рік); О.В. Фільчаков «Міжнародний досвід прокурорського нагляду за додержанням законності при проведенні оперативно-розшукових заходів підрозділами кримінальної поліції» (2018 рік);

- проведення ОРЗ за видами:

а) візуальне спостереження: Б.К. Слободянюк «Візуальне спостереження: оперативно-розшуковий захід чи оперативно-розшуковий метод?» (2006 рік); Н.Ф. Войтович «Правові та організаційно-тактичні засади візуального спостереження» (2012 рік); 0.0. Сухачов «Забезпечення конспірації візуального спостереження за особою, річчю або місцем» (2014 рік); 0.О. Пустовий «Використання візуального спостереження у протидії масовим заворушенням» (2017 рік); Л.М. Лоневський «Пошуково-пізнавальне значення результатів оперативно-розшукового заходу спостереження за особою, річчю або місцем для досудового розслідування ухилення від сплати податків, зборів (обов'язкових платежів)» (2018 рік);

б) зняття інформації з електронних інформаційних мереж: А.І. Воронов «Спеціальні методи зняття інформації з комп'ютерів під час проведення оперативно-розшукових заходів» (2004 рік);

в) зняття інформації з каналів зв'язку: $Є$.Д. Лук'янчиков «Зняття інформації з каналів зв'язку в оперативно-розшуковій і слідчій практиці» (2004 рік); І.В. Сервецький, Г.О. Якименко «Зняття інформації з каналів зв'язку: оперативний захід чи слідча дія» (2005 рік); Л.Ф. Гула, С.А. Капітанчук «Проблемні питання щодо 
проведення оперативно-розшукових заходів зняття інформації з технічних каналів зв'язку» (2006 рік);

г) контроль за телефонними розмовами: М.О. Волошина «Теоретичні та прикладні засади проведення контролю за телефонними розмовами підрозділами Національної поліції» (2018 рік);

ґ) контрольована поставка: Ю.В. Тузов, К.Г. Костенко «Використання контрольованої поставки під час проведення оперативно-розшукових заходів по документуванню контрабанди наркотичних речовин» (1999 рік); К.Г. Костенко «Контрольована поставка: правова основа, організаційні та тактичні аспекти» (2008 рік); О.В. Кондратюк «Застосування контрольованого постачання, оперативної і контрольованої закупівель оперативними підрозділами органів внутрішніх справ України» (2013 рік); А.Д. Онофрейчук «Теоретико-прикладне осмислення сутності контрольованої поставки» (2014 рік) і «Правові та організаційні основи проведення контрольованої поставки та оперативної закупки» (2015 рік);

д) особистий пошук та оперативний огляд публічно доступного місця: О.І. Козаченко «Тактичні особливості здійснення особистого пошуку в розкритті грабежів» (2006 рік); Р.Д. Дарага «Особливості оперативного пошуку та оперативна розробка осіб в сучасних умовах» (2013 рік);

ж) оперативний огляд: Л.В. Головіна «Оперативний огляд - ефективний метод боротьби зі злочинністю» (2006 рік); В.О. Колінко «Проведення оперативного огляду підрозділами кримінальної поліції» (2018 рік);

з) оперативна закупка: В.П. Меживой «Місце оперативної закупівлі та контрольованого постачання зброї серед оперативно-розшукових заходів, методів та операцій» (2003 рік); І.В. Сервецький, В.А. Дашко «Оперативна закупівля - спеціальна оперативно-розшукова операція» (2006 рік); К.А. Мулик «Організація і тактика проведення спецпідрозділами «К» СБ України оперативної закупівлі та контрольованого постачання» (2010 рік); О.В. Кириченко «Особливості проведення оперативної закупки щодо злочинів, пов'язаних із незаконним обігом вогнепальної зброї, бойових припасів, вибухових речовин, в сучасних умовах» (2013 рік); О.І. Козаченко «Контроль за вчиненням злочину: порядок та тактика проведення оперативної закупки» (2015 рік); С.Ю. Попов «Проведення оперативної закупки підрозділами кримінальної поліції» (2018 рік);

i) впровадження негласного працівника в організовані групи та злочинні організації: В.А. Маліков «Деякі методи негласного впровадження в злочинні угрупування» (1992 рік); В.А. Некрасов «Проблеми негласного проникнення в злочинне середовище (за матеріалами діяльності оперативних підрозділів ОВС)» (2001 рік); Р.В. Тарасенко «Впровадження негласного співробітника в оперативну розробку як комплексний захід ОРД» (2004 рік); В.В. Гриценко «Організація і тактика впровадження штатних негласних працівників оперативних підрозділів податкової міліції у злочинне середовище та легендування ОРД із використанням можливостей конспіративних підприємств» (2006 рік); О.В. Ільїн «Оперативний контроль за кримінальним середовищем» (2012 рік); С.І. Пічкуренко «Поняття, сутність і кваліфікаційні ознаки спеціального завдання $з$ розкриття злочинної діяльності організованої групи чи злочинної організації» (2015 рік); О.В. Ігнатюк «Організаційно-тактичні основи виконання спеціального завдання 3 розкриття злочинної діяльності організаційної групи чи злочинної організації» (2017 рік).

Висновки. Підсумовуючи результати аналізу спеціальної літератури, присвяченої питанням проведення ОРЗ оперативними підрозділами (ПКП), можна стверджувати, що:

1. На сучасному етапі розвитку теорія проведення OP3 накопичила величезний емпіричний матеріал і на його основі визначила систему окремих понять, категорій, сформулювала низку практичних рекомендацій.

2. Набуття Україною незалежності і прийняття закону про ОРД стало поштовхом для наукового осмислення вченими підстав та умов проведення ОРЗ, порядку проведення ОРЗ й використання отриманих результатів у кримінальному судочинстві.

3. На сьогоднішній день теорія дослідження проведення ОРЗ підрозділами кримінальної поліції увійшла в найважчий етап свого становлення, який характеризується конкретизацією іï предмета, методів і системи проведення, формулюванням світоглядних принципів і теоретичних концепцій.

4. Успішна розробка та завершення комплексних досліджень, які стосуються проведення ОРЗ підрозділами кримінальної поліції, які зроблять вагомий внесок у розвиток теорії ОРД, нададуть допомогу практиці, дозволять покращити якість навчального процесу, підвищать наукову кваліфікацію викладачів.

\section{Література}

1. Александров А.И. Уголовно-процессуальная политика России в условиях реформирования государства: теория и современность : монография. СПб., 1998. 324 с.

2. Лекарь А.Г., Волынский А.Ф., Гребельский Д.В., Самойлов В.Г. Методологические проблемы теории оперативно-розыскной деятельности органов внутренних дел // Труды Киевской высшей школы МВД СССР. Киев, 1976. С. 3-34.

3. Елинский В.И. Основы методологии теории оперативно-розыскной деятельности : монография. М. : Издатель Шумилова И.И., 2001. 228 с.

4. Лукашов В.А. Предмет теории оперативно-розыскной деятельности // Оперативно-розыскная деятельность. Учебник / Под ред. К.К. Горяинова, В.С. Овчинского, А.Ю. Шумилова. М. : ИНФА-М, 2001.

5. Карпинець Т.М. Оперативно-розшукові заходи: вдосконалення правового регулювання // Бюлетень обміну досвідом роботи : науково-практичне видання МВС України. К., 2013. № 193. С. 85-92.

Капустник В. В., докторант Харківського національного університету внутрішніх справ 